\title{
Autophagy is involved in oligodendroglial precursor-mediated clearance of amyloid peptide
}

\author{
Wenxia Li ${ }^{1}$, Yifen Tang ${ }^{1}$, Zhiqin Fan', Ya Meng ${ }^{1}$, Guang Yang ${ }^{1}$, Jia Luo ${ }^{2^{*}}$ and Zun-Ji Ke $\mathrm{K}^{1,3^{*}}$
}

\begin{abstract}
Background: Accumulation of $\beta$-amyloid peptides is an important hallmark of Alzheimer's disease (AD). Tremendous efforts have been directed to elucidate the mechanisms of $\beta$-amyloid peptides degradation and develop strategies to remove $\beta$-amyloid accumulation. In this study, we demonstrated that a subpopulation of oligodendroglial precursor cells, also called NG2 cells, were a new cell type that can clear $\beta$-amyloid peptides in the AD transgene mice and in NG2 cell line.

Results: NG2 cells were recruited and clustered around the amyloid plaque in the APPswe/PS1dE9 mice, which is Alzheimer's disease mouse model. In vitro, NG2 cell line and primary NG2 cells engulfed $\beta$-amyloid peptides through the mechanisms of endocytosis in a time dependent manner. Endocytosis is divided into pinocytosis and phagocytosis. $A \beta_{42}$ internalization by NG2 cells was mediated by actin-dependent macropinocytosis. The presence of $\beta$-amyloid peptides stimulated the autophagic pathway in NG2 cells. Once inside the cells, the $\beta$-amyloid peptides in NG2 cells were transported to lysosomes and degraded by autophagy.
\end{abstract}

Conclusions: Our findings suggest that NG2 cells are a new cell type that can clear $\beta$-amyloid peptides through endocytosis and autophagy.

Keywords: Alzheimer's disease, $\beta$-amyloid degradation, Autophagy, Endocytosis, NG2 cells

\section{Background}

The major neuropathological hallmarks of Alzheimer's disease (AD) are selective loss of neurons and the formation of amyloid plaques and neurofibrillary tangles [1]. It is suggested that accumulation of $\beta$-amyloid peptides $(\mathrm{A} \beta)$ plays a central role in pathophysiological procedure of $\mathrm{AD}[2,3]$. Cellular engulfment of $\mathrm{A} \beta$ is an important mechanism for clearing the harmful protein in the brain; microglia, astrocyte and neuron are known cell types capable of clearing $A \beta$ through various putative receptors and transporters [4]. Once internalized, $A \beta$ can be degraded by various proteases. Autophagy is an important cellular self-regulatory process involving protein degradation and recycling. It is essential in maintaining

\footnotetext{
* Correspondence: jialuo888@uky.edu; zjke@sibs.ac.cn

${ }^{2}$ Department of Internal Medicine, University of Kentucky College of Medicine, Lexington, KY 40536, USA

${ }^{1}$ Key Laboratory of Nutrition and Metabolism, Institute for Nutritional Sciences, Shanghai Institutes for Biological Sciences, Chinese Academy of Sciences, Graduate School of the Chinese Academy of Sciences, Shanghai 200031, China

Full list of author information is available at the end of the article
}

neuronal homeostasis, and its dysfunction has been directly linked to a number of neurodegenerative disorders $[5,6]$. Recent finding suggests that $A \beta$ may be degraded by autophagy/lysosome pathway [7].

In the brain, a subpopulation of glia termed oligodendroglial precursor cells (OPCs). These cells express NG2 (a chondroitin sulfate proteoglycan), are therefore called NG2 cells $[8,9]$, they are distinct from astrocytes, microglia, mature oligodendrocytes and neurons [10]. NG2 cells are abundant in adult brain and comprise 5$8 \%$ of brain cells [11]. Morphologically, NG2 cells have small cell bodies and multiple branched processes. In grey matter, these processes tend to have a radial orientation, whereas in white matter, the processes are more longitudinal and aligned with the nerve fibers. These fine cellular processes also ensheath synaptic profiles [12]. Neurons also have synaptic junctions with NG2 cells $[13,14]$. It is suggested that NG2 cells are a widely distributed stem-like cells in the adult brain. Usually, NG2 cells are induced to differentiate to glial cells, but under the appropriate circumstances, they might generate neurons [15,16]. More importantly, NG2 cells become

\section{() Biomed Central}

(c) 2013 Li et al.; licensee BioMed Central Ltd. This is an Open Access article distributed under the terms of the Creative Commons Attribution License (http://creativecommons.org/licenses/by/2.0), which permits unrestricted use, distribution, and reproduction in any medium, provided the original work is properly cited. 
rapidly activated in response to a variety of CNS insults, including physical trauma [17], excitotoxic lesions [18], viral infection [19], and exposure to chemicals [20].

In this study, we examined the role of NG2 cells in $\mathrm{A} \beta_{42}$ clearance in mice. We demonstrated that the number of active NG2 cells was increased and the cells were clustered around the amyloid plaque. In addition, cultured NG2 cells were able to uptake and clear $A \beta_{42}$. Upon internalization most of the $A \beta_{42}$ is transported to lysosomes and degraded by autophagy-lysosome pathway. Our results indicate that NG2 cells can reduce $A \beta_{42}$ through endocytosis and degrade $A \beta_{42}$ by autophagy-lysosome pathway.

\section{Results}

\section{NG2 cells clustered around the amyloid plaque}

It has been demonstrated that the number of NG2 cells as well as the expression of NG2 molecules increases and the cells become hypertrophic surrounding the damage sites in various brain injury models [18,20-23]. We examined the localization and morphology of the NG2 cells in the APPswe/PS1dE9 mice, which express familial AD-causing mutated forms of human APP (APPswe, Swedish familial AD-causing mutation) and presenilin1 (PS1dE9). NG2-positive cells became hypertrophic in the cortex of APPswe/PS1dE9 mice (Figure 1A) and clustered around the amyloid plaques (Figure 1B) in 14-month-old APPswe/PS1 mice. The number of activated NG2 cells increased around 2 fold in 15-monthold APPswe/PS1 mice when compared with control mice (Figure 1C). In addition, the expression of NG2 mRNA increased more than 1.5 fold in 12-month-old APPswe/ PS1dE9 mice compared to age matched wild type mice (Figure 1D).

\section{Engulfment of $A \beta_{42}$ by $N G 2$ cells}

Microglia and astrocytes are activated and cluster around amyloid plaques in the brain of $\mathrm{AD}$ patients, and both of the cells, especially microglia, play an important role in clearing $A \beta$ [24-27]. The $A \beta_{42}$ variant is more hydrophobic and more prone to fibril formation than $A \beta_{40}$ and it is this longer form that is also the predominant isoform found in cerebral plaques [4]. $A \beta_{42}$ was used in our all experiment. To determine whether NG2 cells were able to engulf $A \beta_{42}$, we incubated the primary NG2 cells with fluorescence-labeled $A \beta_{42}$. The fluorescencelabeled $A \beta_{42}$ was visualized within NG2 cells after 24 hours (Figure 2A). Like primary NG2 cells, NG2 cell line was also able to engulf $A \beta_{42}$ (Figure $2 B$ ). The electron microscopy further confirmed that the $A \beta_{42}$ was distributed in the cytosol of NG2 cells (Figure $2 \mathrm{C}$ ). The density of fluorescence-labeled $A \beta_{42}$ initially increased after incubation for one hour, and levels further increased as incubation time increased (Figure 3). Furthermore, the engulfment of $A \beta_{42}$ by NG2 cells was concentrationdependent (Figure 3D).

\section{Actin is involved in the engulfment of $A \beta_{42}$}

The phagocytosis and pinocytosis are two major forms for cells to uptake extracellular substances. Microglia can engulf $A \beta$ by macropinocytosis [27]. To determine the mechanism for the engulfment of $\mathrm{A} \beta_{42}$ by NG2 cells, we treated the NG2 cell line with nocodazole that causes depolymerization of microtubules and cytochalasin $\mathrm{D}$ that inhibits actin polymerization. The cytochalasin $\mathrm{D}$ reduced the engulfment of $A \beta_{42}$ measured by flow cytometry (Figure 4A). Nocodazole had little effect on $A \beta_{42}$ internalization after 3 hours of exposure but modestly increased $\mathrm{A} \beta_{42}$ content following 6 hours of exposure (Figure 4B).

\section{The $A \beta_{42}$ was degraded by lysosome pathway}

To determine the fate of $A \beta_{42}$ after its internalization, we examined the $A \beta_{42}$ content in cellular fraction in NG2 cell line and cell-culture supernatant. $A \beta_{42}$ in the cellular fraction increased within 3 hours of $A \beta_{42}$ incubation then decreased from 24 hours, indicating that $A \beta_{42}$ was first internalized and then degraded (Figure 5A). The $A \beta_{42}$ in the culture supernatant decreased over time, supporting that $\mathrm{A} \beta_{42}$ was taken up by the cells. To determine whether lysosome pathway is involved in $A \beta_{42}$ degradation, we investigated the intracellular distribution of $A \beta_{42}$ after its internalization. NG2 cell line was exposed to HiLyte Fluor $^{\mathrm{m}}$-488-labeled $A \beta_{42}$ and lysotracker dye for visualizing lysosomes. As shown in Figure $5 B, A \beta_{42}$ is localized in lysosomes. $A \beta_{42}$ exposure also increased the mRNA expression of Lysosomal-associated membrane proteins (LAMP), LAMP1 and LAMP2 (Figure 5C). Leupeptin and pepstatin, the inhibitors for major cysteine and aspartyl proteases for lysosomal proteolysis, blocked the degradation of $A \beta_{42}$ in the NG2 cells (Figure $5 \mathrm{D}$ ). These data suggested that internalized $A \beta_{42}$ was transported into the lysosome and degraded by the lysosome-dependent pathway.

\section{Autophagy involved in the degradation of $A \beta_{42}$ in NG2 cells}

Since autophagy is involved in amyloid-beta peptide metabolism and clearance $[7,28-30]$, we tested whether autophagy regulated the degradation of $\mathrm{A} \beta_{42}$ in NG2 cells. $A \beta_{42}$ treatment increased the expression of autophagy related proteins, including LC3 and beclin1 (Figure 6A). Furthermore, $A \beta_{42}$ was co-localized with LC3, suggesting that they were enclosed by autophagosomes (Figure 6B). $\mathrm{A} \beta_{42}$ treatment increased the number of mCherry-LC3 puncta-positive cells, suggesting an induction of autophagy (Figure 6C). Autophagy inhibitors, wortmannin (Figure 6D) and bafilomycin A1 (Figure 6E), decreased the $A \beta_{42}$ degradation. The expression of LC3-II dec- 


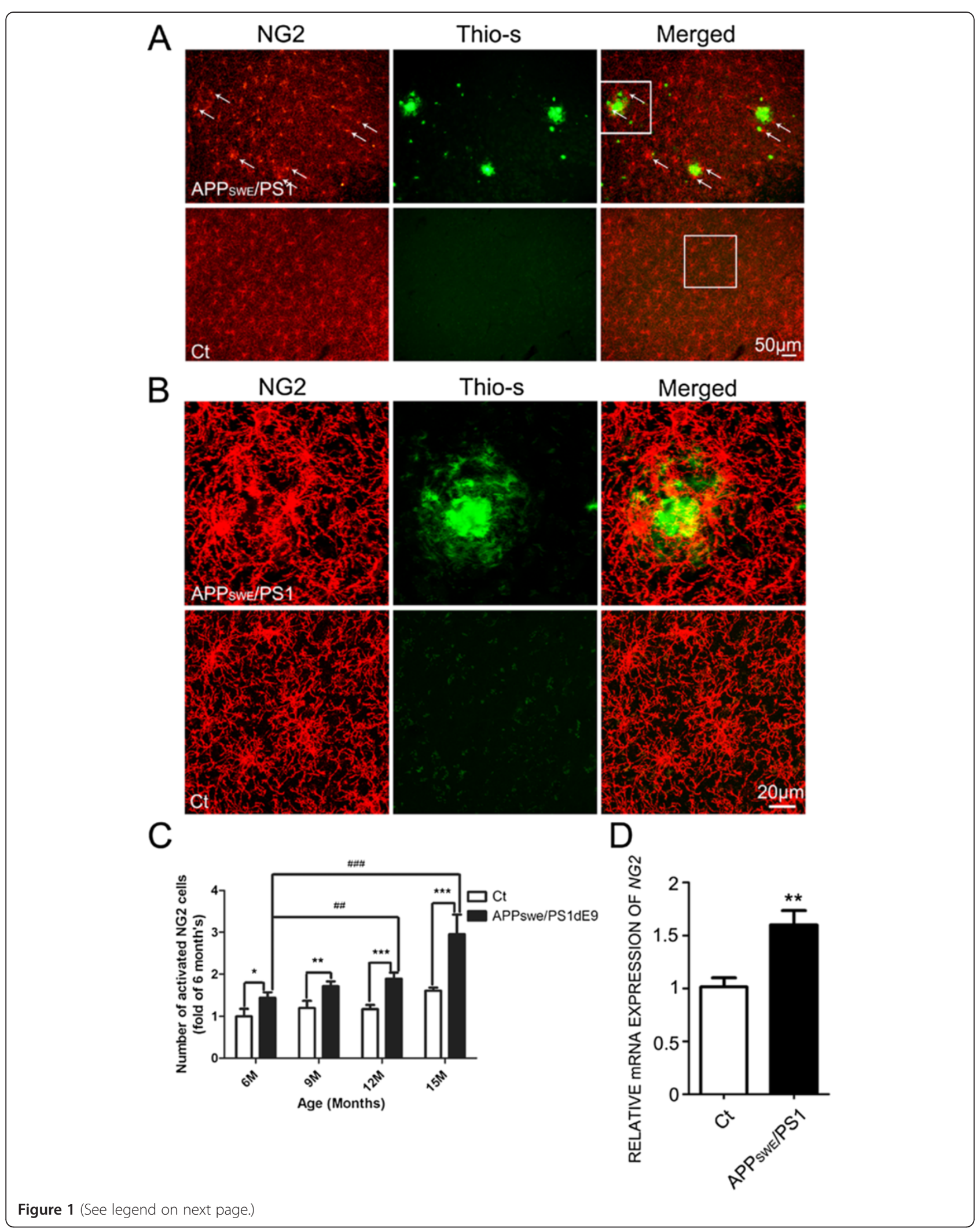


(See figure on previous page.)

Figure 1 The presence of NG2 cells adjacent to the amyloid plaque. A. The presence of NG2 cells in the cortex of 14-month-old APPswe/PS1 mice (top) and control mice (bottom) was demonstrated by immunohistochemistry (IHC) using an anti-NG2 antibody. The amyloid plaque was demonstrated by thioflavin-S staining. Scale bars $=50 \mu \mathrm{m}$. B. A specified area in panel $\mathbf{A}$ is shown with higher magnifications. Scale bars $=20 \mu \mathrm{m}$. C. Activated NG2 cells in the hippocampus of APPswe/PS1 mice (6-15-month-old) and age matched control mice were quantified as described under the Materials and Methods. The results were presented as mean \pm SD of five animals. ${ }^{* *} p<0.01,{ }^{* * *} p<0.001$, compared to age matched control mice. $\# \# p<0.01$, \#\#\#p < 0.001, compared to 6-month-old APPswe/PS1 mice. D: The expression of NG2 mRNA in 12-month-old mice was determined by real time PCR as described under the Materials and Methods. The results were presented as mean \pm SEM of five animals. ${ }^{* *} p<0.01$, compared to age matched control mice.

reased when treated with wortmannin (Figure 6D) and increased when treated with bafilomycin A1 (Figure 6E). Beclin1 did not show changes when treated with wortmannin (Figure 6D) or when treated with bafilomycin A1 (Figure 6E) in NG2 cells. Knockdown of beclin1 in NG2 cells using a beclin1 specific siRNA also increased the accumulation of $A \beta_{42}$ (Figure 6F). Together, these results suggest that $A \beta_{42}$ could induce autophagy which directed $A \beta_{42}$ to lysosome-dependent protein degradation in NG2 cells.

\section{Discussion}

Amyloid plaques, which consist of aggregates of $A \beta$ in the brain, are the predominant pathological change in $\mathrm{AD}$ patients. The overload of $A \beta$ combined with hyperphosphorylated neurofibrillary tangles (NFTs), neuronal loss,
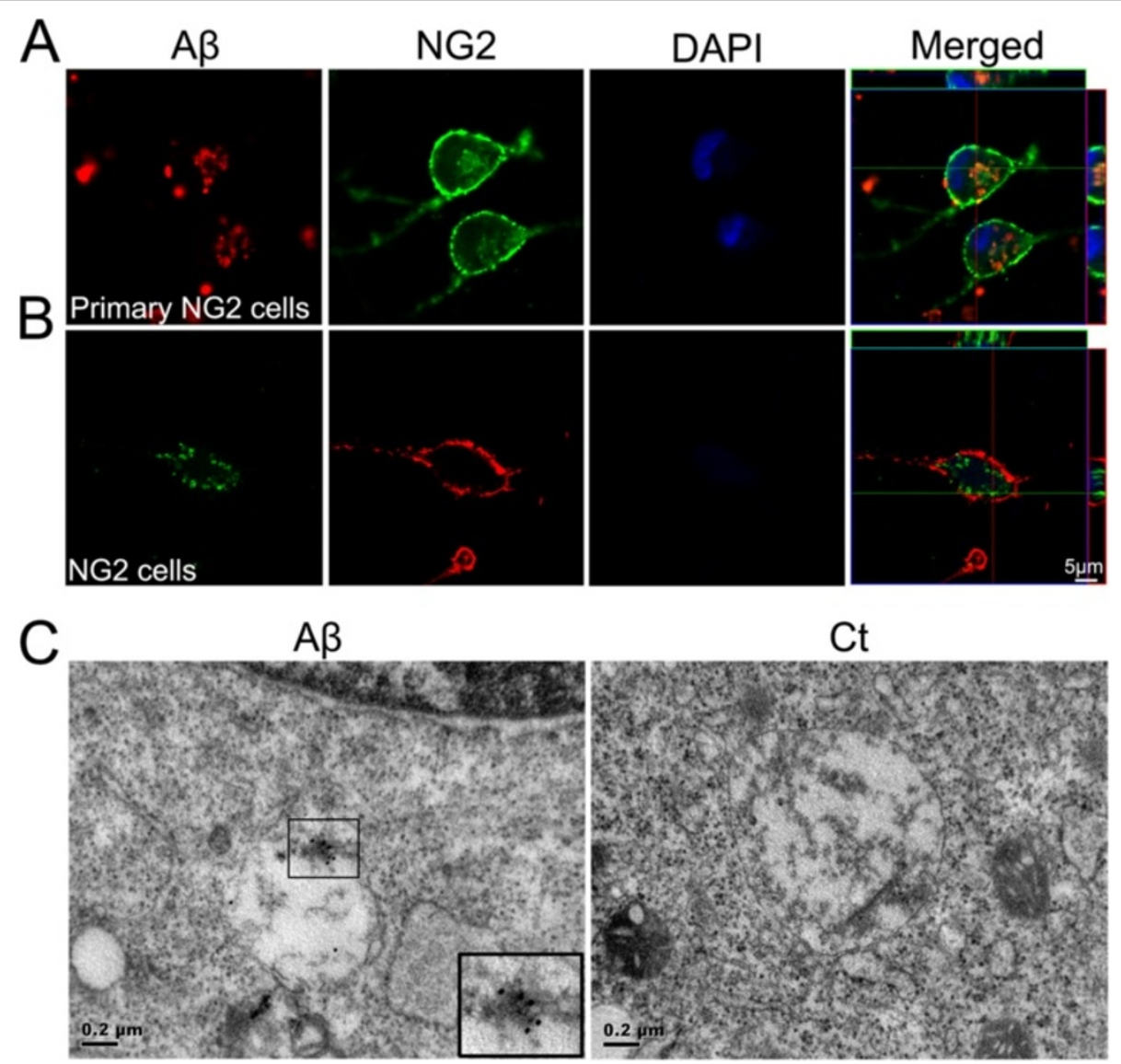

Figure $\mathbf{2} \mathbf{A} \boldsymbol{\beta}_{\mathbf{4 2}}$ uptake by NG2 cells. Primary NG2 cells (A) and NG2 cell line (B) were plated on coverslips for 18 hours and then incubated with HiLyte Fluor ${ }^{\text {TM }} 555 / 488$-labeled $A \beta_{42}(2 \mu \mathrm{M})$ for 24 hours. Cells were then fixed and stained with anti-NG2 antibody. Cell nuclei were visualized by DAPI staining (blue). A $\beta_{42}$ was engulfed by primary cultured NG2 cells and NG2 cells. Scale bars $=5 \mu \mathrm{m}$. C. A $\beta_{42}$ uptake by NG2 cell line was shown by transmission electron microscopy (TEM). NG2 cell line were exposed to $A \beta_{42}$ for 6 hours, stained with anti-A $\beta_{42}$ lgG antibody followed by donkey anti-rabbit antibody conjugated to colloidal gold ( $18 \mathrm{~nm}$ particle), then processed by TEM. Internalized $A \beta_{42}$ was demonstrated. The inset is an image of internalized $A \beta_{42}$ with higher magnification. Scale bars $=0.2 \mu \mathrm{m}$. 

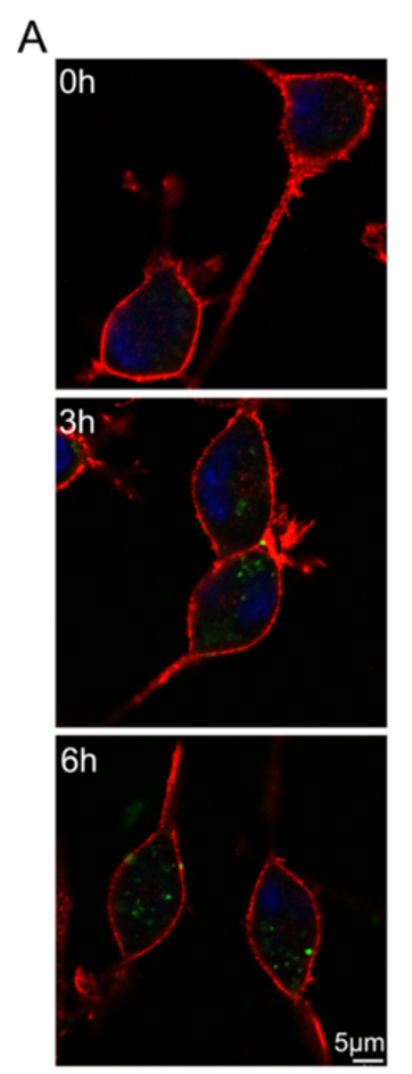

B

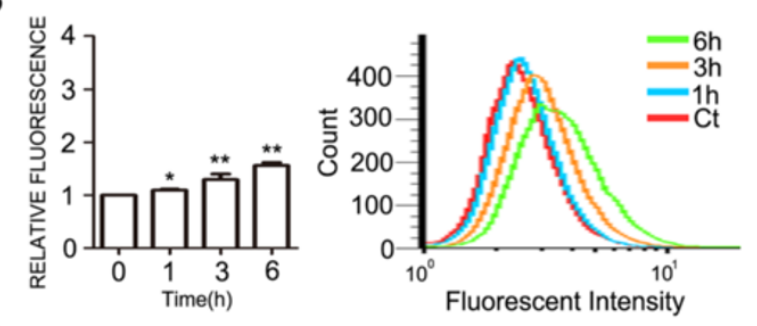

C
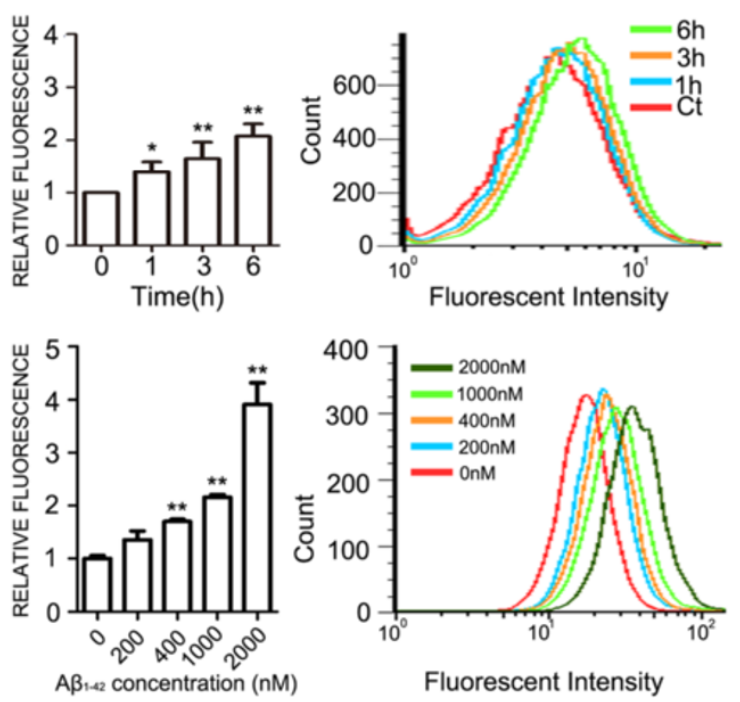

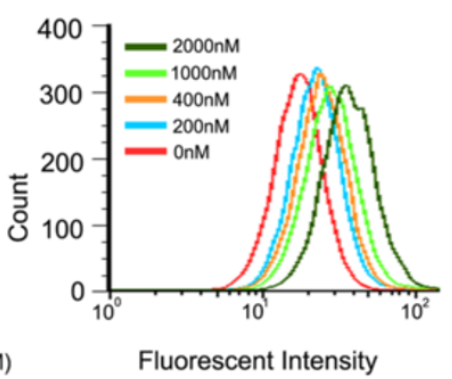

Figure 3 The time sequence of engulfment of $\mathbf{A} \boldsymbol{\beta}_{\mathbf{4 2}}$ by $\mathbf{N G} \mathbf{2}$ cells. $\mathbf{A}$. NG2 cell line was incubated with HiLyte Fluor ${ }^{\mathrm{TM}} 488-\mathrm{labeled} A \beta_{42}$ $(400 \mathrm{nM})$ for the indicated times, and stained with anti-NG2 antibody. A $\beta_{42}$ appeared inside the cells after 6 hours of $A \beta_{42}$ incubation. Scale bars $=5 \mu \mathrm{m}$. B-C. A $\beta_{42}$ engulfed by NG2 cells was quantified with flow cytometry. NG2 cell line (B) and primary NG2 cells (C) were incubated with HiLyte Fluor ${ }^{\mathrm{TM}} 488$-labeled $A \beta_{42}(400 \mathrm{nM})$ for the indicated times. The amount of $A \beta_{42}$ inside cells were quantified by measuring the intensity of fluoresce with flow cytometry. Data were presented as mean $\pm S D$; ${ }^{*} p<0.05$, ${ }^{* *} \mathrm{p}<0.01$, compared with cells treated with $A \beta_{42}$ for 0 hours. The experiments were replicated three times. D. The engulfment of $A \beta_{42}$ by NG2 cells was concentration-dependent. NG2 cell line was incubated with HiLyte Fluor ${ }^{\top M}$ 488-labeled $A \beta_{42}$ for the indicated concentrations. The amount of $A \beta_{42}$ inside cells were quantified by measuring the intensity of fluoresce with flow cytometry. Data were presented as mean \pm SD; ${ }^{* *} \mathrm{p}<0.01$, compared with cells treated without $A \beta_{42}$. The experiments were replicated three times.

inflammation, and oxidative stress make synaptic dysfunction and behavioral changes [31,32]. It is important to understand the mechanisms underlying the clearance of the amyloid protein in the brain. The levels of $A \beta$ peptides within the brain are tightly regulated by mechanisms controlling their generation and clearance [3]. In human $\mathrm{CNS}$, the rate for production and clearance of $A \beta$ is $7.6 \%$ per hour and $8.3 \%$ per hour, respectively; therefore there is no accumulation and deposition of $A \beta$ in the normal brain [33]. However, even a modest perturbation in $A \beta$ clearance will result in an imbalance between production and clearance, and cause an accumulation of $\mathrm{A} \beta$ peptides within the brain and their subsequent deposition into plaques. The excessive accumulation of $A \beta$ may trigger the onset of AD, as suggested by the "amyloid hypothesis" [2]. Activated microglial cells and astrocytes are associated with amyloid plaques [24,25,27,34,35]. Microglia and astrocytes are shown to engulf and degrade $A \beta$ in vitro and in situ $[24,25,27,34]$. In this study, we demonstrate that
NG2 cells are recruited and clustered in the area adjacent to amyloid plaques. The number of active NG2 cells is increased and NG2 mRNA is upregulated. NG2 cells are able to internalize and degrade $A \beta_{42}$ and a new cell type to clear $A \beta$.

\section{Mechanisms of NG2 cell-mediated $A \beta_{42}$ uptake}

Extracellular substances can be taken up by cells and transported to intracellular compartments through two major pathways, the phagocytosis and the pinocytosis. Phagocytosis is restricted to specialized phagocytic cells and is responsible for receptor-dependent uptake of large particles such as bacteria. Pinocytosis encompasses several distinct mechanisms [36,37]. Macropinocytosis belongs to dynamin-independent pinocytosis, which can be defined as a transient, growth factor-induced, actin-dependent endocytic process that leads to internalization of fluid and membrane into large vacuoles [38]. Macropinosome formation is an actin based process. Vacuole formation is 


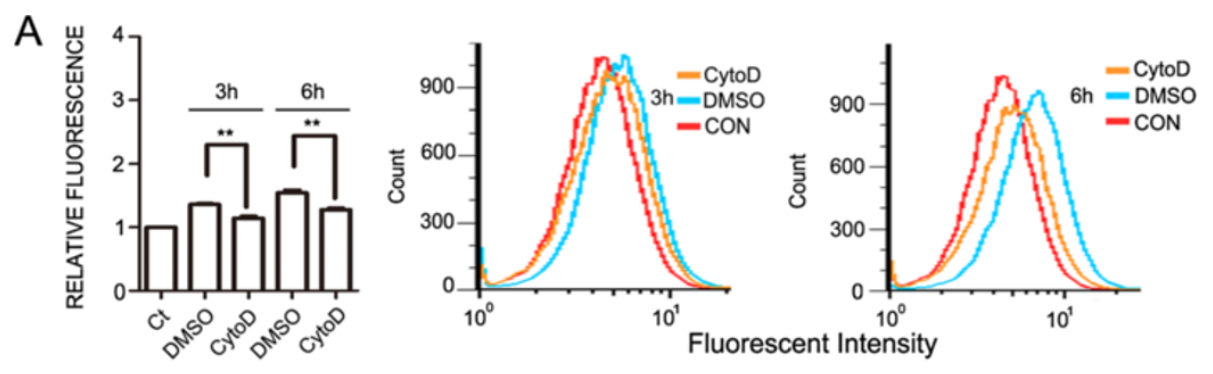

B

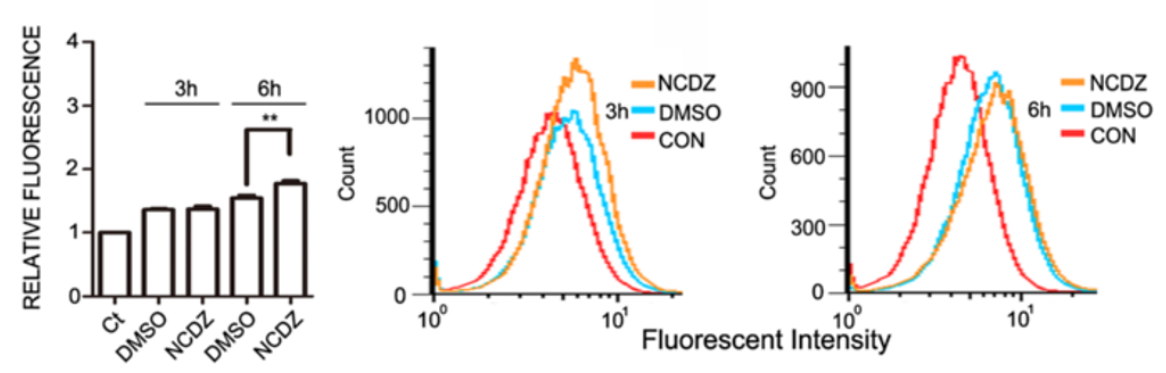

Figure 4 Effect of cytochalasin $D$ and nocodazole on $A \boldsymbol{\beta}_{\mathbf{4 2}}$ uptake by NG2 cells. NG2 cell line were treated with cytochalasin D (A), an inhibitor of actin polymerization or nocodazole (B), an agent that disrupts microtubule dynamics for 30 minutes prior to the addition of HiLyte Fluor ${ }^{\text {TM }}$ 488-labeled $A \beta_{42}(400 \mathrm{nM})$ for the indicated times. The amount of $A \beta_{42}$ inside cells were quantified by measuring the intensity of fluoresce with flow cytometry. Data were presented as mean $\pm S D$; ${ }^{* *} p<0.01$, compared with cells without any treatment $(\mathrm{Ct})$. The experiments were replicated three times.

probably the result of local actin cortex destabilization [37]. A recent study suggests that microglia internalize $A \beta$ through fluid phase macropinocytosis [27]. Cytochalasin $\mathrm{D}$, the inhibitor of actin polymerization, inhibited the engulfment of $A \beta_{42}$ by NG2 cells, and nocodazole, the inhibitor of tubulin polymerization had little effect on $A \beta_{42}$ engulfment. Microtubules have diverse roles in the cellular function, including vesicular transportation that facilitates $A \beta_{42}$ degradation. They play a role in late steps of endocytosis and are involved in the traffic between early and late compartments [39]. Translocation of endosomes and lysosomes occurs along microtubules and is independent of the intermediate filament and microfilament networks [40,41]. When the microtubules are depolymerized with nocodazole, translocation of endosomes and lysosomes is inhibited, which will affect the transportation of $\mathrm{A} \beta_{42}$ for its degradation in lysosome, resulting in accumulation of $\mathrm{A} \beta_{42}$ in cytoplasm. Our data did show nocodazole modestly increased $A \beta_{42}$ amount in NG2 cells. These results suggest that $A \beta_{42}$ internalization by NG2 cells may be mediated by actin-dependent macropinocytosis and the microtubule-dependent process may be involved in its degradation.

The accumulation of $A \beta$ results from the impairment of balance between producing and clearance of $A \beta$. So far, activated microglia and astrocytes are known cell types that can engulf $A \beta$. Apart from activated microglia and astrocytes, neurons can internalize $A \beta$ peptide. Our results show that both primary NG2 cells and NG2 cell lines are able to engulf and clear $\mathrm{A} \beta_{42}$, adding a new cell type to clear $A \beta$ in CNS. The time sequence of NG2 cell uptake of $A \beta_{42}$ is similar to that of microglia [27]. Based on our observation the ability of NG2 cells to clear $A \beta$ is much weaker than microglia. Therefore, in $A D$ brain, microglia is the major cell type to clear $A \beta$. Microglia expresses a number of putative $A \beta$ transporters, such as scavenger receptor for advanced glycation end products (RAGE) [42], formyl peptide receptor-like 1 (FPRL1) $[43,44]$ and toll-like receptors (TLRs) [45]. These transporters may facilitate microglia-induced clearance of $A \beta$. Mandrekar et al. (2009) also demonstrate that microglia uptake of $A \beta$ is mediated by fluid phase macropinocytosis both in vitro and in vivo, and tubulin depolymerization and actin polymerization are required for the process [27]. Our data support that NG2 cell-mediated $\mathrm{A} \beta_{42}$ uptake depends on actin polymerization but not tubulin depolymerization.

Cytochalasin D does not completely inhibit $A \beta_{42}$ internalization in NG2 cells, suggesting that there may be other pathways that participate in $A \beta_{42}$ internalization. $A \beta$ can bind to various membrane biomolecules, including lipids, proteins and proteoglycans. A number of putative $A \beta$ transporters have been identified, such as $\alpha 7$ nicotinic acetylcholine receptor $(\alpha 7 \mathrm{nAChR})$ [46], apolipoprotein $\mathrm{E}$ (ApoE) receptors [47], members of the low-density lipoprotein receptor (LDLR) family [48], scavenger receptor for advanced glycation end products (RAGE) [49], formyl peptide receptor-like 1 (FPRL1) [43,44] and toll-like recep- 


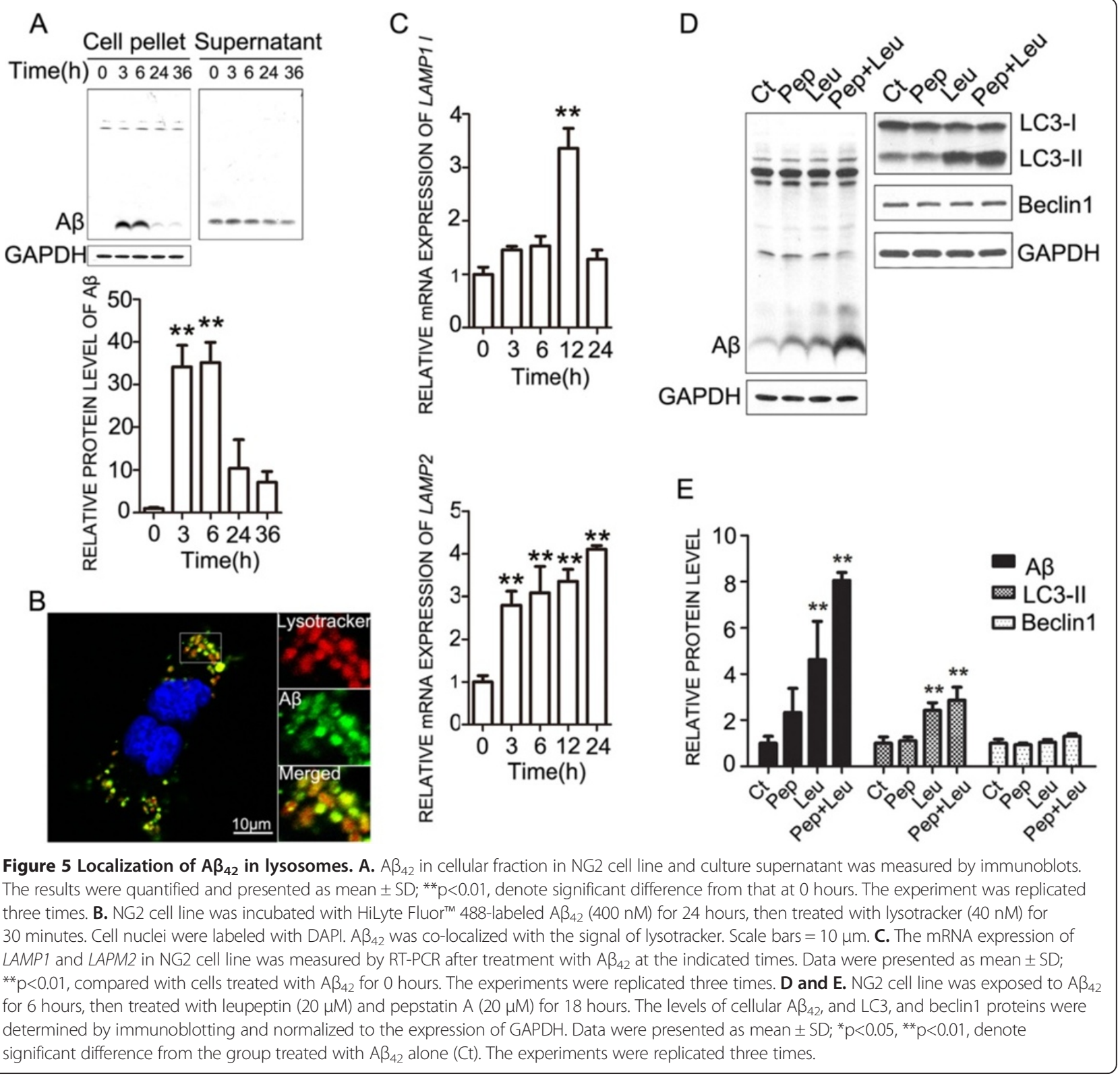

tors (TLRs) [4]. It is likely that $\mathrm{A} \beta$ also can be internalized through these receptors or transporters.

\section{Mechanisms of NG2 cell-mediated $A \beta_{42}$ degradation}

Recent studies suggest that autophagy/lysosome pathway (ALP) is an important and perhaps compensatory mechanism for intracellular protein degradation [50,51]. The accumulation of lysosomes and their hydrolases within neurons is a well-established neuropathologic feature of AD. The endosomal-lysosomal system is reported to be activated in vulnerable neurons in $\mathrm{AD}$ brains [52,53]. It has been suggested that the autophagy/lysosome pathway is involved in the degradation of $\mathrm{A} \beta$ [28]. Autophagosomes and other prelysosomal autophagic vacuoles were abundant in AD brains. The transport of autophagic vacuoles and their maturation to lysosomes is impaired, resulting in the accumulations of immature autophagic vacuoles and the inhibition of $A \beta$ clearance [54]. We showed that $A \beta_{42}$ was localized to lysosomes after internalization and the expression levels of lysosomal-associated membrane protein 1 and 2 genes were increased. Moreover, the degradation of $A \beta_{42}$ was inhibited by lysosomal proteolysis inhibitors leupeptin and pepstatin A. The effects of leupeptin supports the role of cysteine protease in 


\section{A}
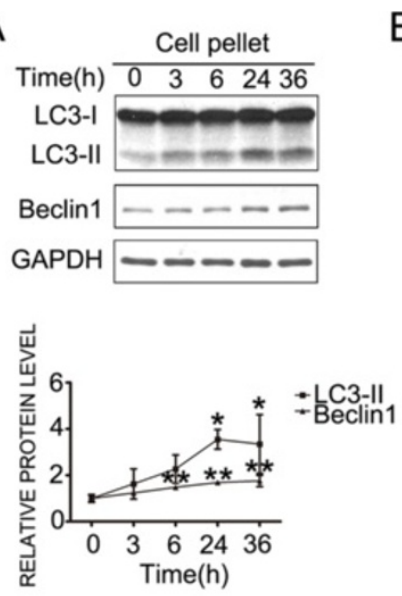

D
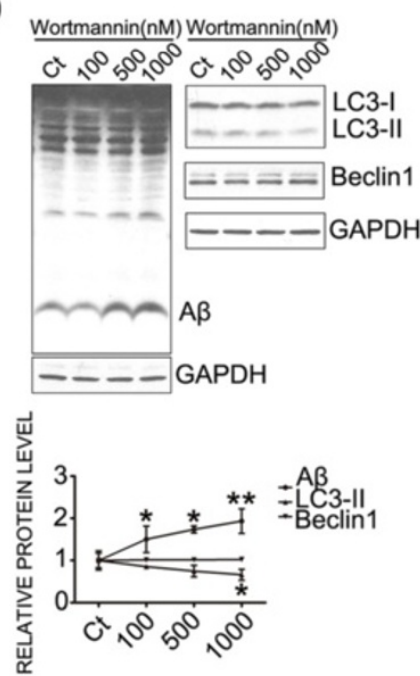
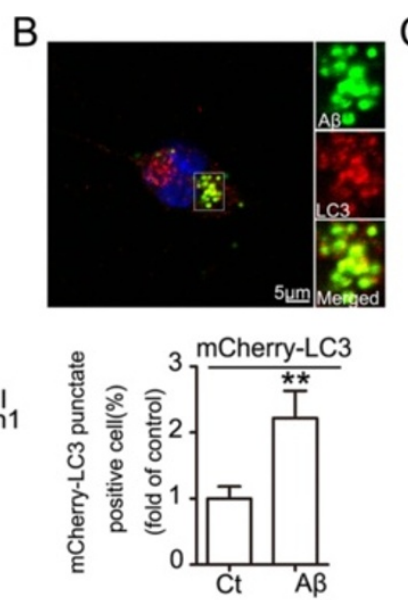

E
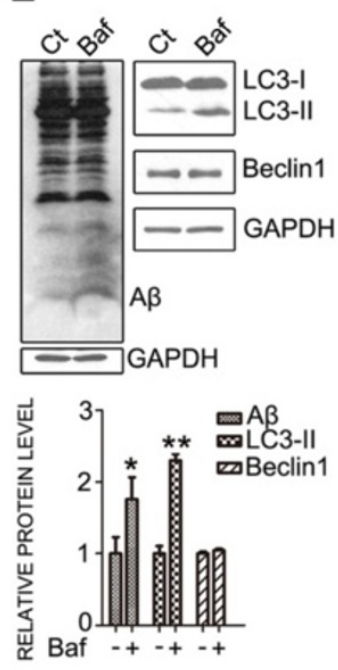

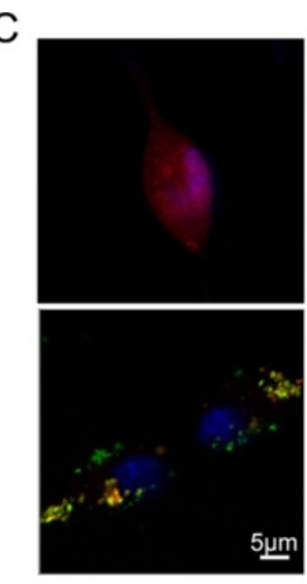

$\mathrm{F}$
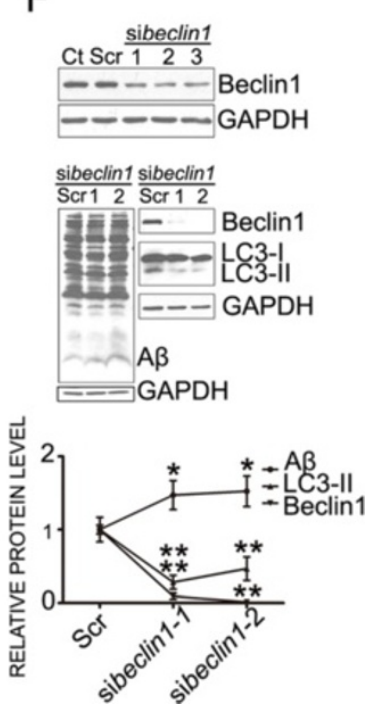

Figure 6 Autophagy was involved in the degradation of $\mathbf{A}_{\mathbf{4 2}_{\mathbf{4 2}}}$. A. NG2 cell line was treated with $A \beta_{42}$ for specified times. The expression of $L C 3-\|$, and beclin1 was determined by immunoblotting. B. NG2 cell line was incubated with HiLyte Fluor ${ }^{\text {TM }}$ 488-labeled A $\beta_{42}(400$ nM) for 24 hours, and immunostained using an anti-LC3-Il antibody. Cell nuclei were labeled with DAPI. Scale bars $=5 \mu \mathrm{m}$. C. NG2 cell line was transiently transfected with a mCherry-LC3 plasmid, and autophagosomes were demonstrated by mCherry-LC3 puncta. Scale bars $=5 \mu \mathrm{m}$. D. NG2 cell line was exposed to $A \beta_{42}$ for 6 hours, and then treated with wortmannin at the indicated concentrations for 18 hours. $A \beta_{42}$, and the expression of $L C 3$, and beclin1 was determined by immunoblotting (top panel). The results were quantified (bottom panel). E. NG2 cell line was exposed to A $\beta_{42}$ for 6 hours, then treated with bafilomycin $\mathrm{A} 1(0.2 \mathrm{nM})$ for 18 hours. $A \beta_{42}$, the expression of $\mathrm{LC} 3$, and beclin 1 was determined by immunoblotting (top panel). The results were quantified (bottom panel). F. Top panel: NG2 cell line treated with specific beclin1 siRNA oligonucleotides (siBeclin1-1, siBeclin1-2, siBeclin1-3), scramble RNA oligonucleotides for 24 hours. The expression of beclin1 was analyzed by immunoblotting. Ct: no treatment; Scr: scramble RNA oligonucleotides. Middle panel: NG2 cell line was transfected with beclin1 siRNA for 24 hours, then treated with $A \beta_{42}$ for another 24 hours. $A \beta_{42}$, the expression of LC3, and beclin 1 was determined by immunoblotting. Bottom panel: Results were quantified. All data were presented as mean $\pm S D ;{ }^{*} p<0.05$, ${ }^{* *} p<0.01$, denote significant difference. All the experiments were replicated three times.

degrading $A \beta$ has been documented in earlier studies [55,56]. Pepstatin $A$ increased $A \beta_{42}$ levels without altering LC3-II or beclin1 levels. This may be due to the relative insensitivity of NG2 cells to pepstatin A and a higher concentration may be necessary. Pepstatin A is an inhibitor of aspartic proteinases such as pepsin, cathepsins $\mathrm{D}$ and $\mathrm{E}$. The optimal concentrations for pepstatin A are different among cell types. Pepstatin A in combination with
Leupeptin did induce more LC3-II accumulation. These results indicated that $A \beta_{42}$ was degraded through the lysosomal pathway.

Protein degradation by the autophagy/lysosomal pathway was initiated by the formation of a double-membrane -limited autophagosome, containing undigested cytoplasmic materials. LC3 serves as a specific marker for autophagy in mammalian cells. It has cytoplasmic form (LC3-I) 
and autophagosome membrane associated form LC3-II. LC3 I can be transferred to phophatidylethanolamine (PE) in the double membrane of the autophagosome and become a lipidated form of LC3 (LC3-II). The ratio of LC3-II to LC3-I is commonly used as a marker of autophagosome formation and autophagy activation. Digestion of sequestered material within autophagosomes is initiated when lysosomes fuse with the outer membrane of the autophagosome, forming autolysosome/autophagolysosome [30]. Beclin1 is a downstream effecter in the autophagy process and is involved in the recruitment of membranes to form autophagosomes [57-59]. Reduction expression of beclin1 increases intraneuronal $\mathrm{A} \beta$ accumulation, extracellular $\mathrm{A} \beta$ deposition, and neurodegeneration in transgenic mice that express human amyloid precursor protein [7]. We demonstrated that $A \beta_{42}$ increased the expression of LC3-II, beclin 1 and LC3 puncta in NG2 cells, indicating that $A \beta_{42}$ could activate autophagy. Furthermore, wortmannin, the chemical inhibitor, and beclin1 siRNA inhibited autophagy and increased $A \beta_{42}$ accumulation in NG2 cells, indicating that $A \beta_{42}$ degradation was at least partially mediated by the autophagy/lysosomal pathway.

\section{Conclusions}

Amyloid plaques, which consist of aggregates of $\beta$-amyloid peptides in the brain, are the predominant pathological change in $\mathrm{AD}$ patients. An imbalance between $\mathrm{A} \beta$ production and clearance will result in accumulation of $A \beta$ peptides and subsequent deposition into plaques. Autophagy may be a protective response to AD during early pathogenesis and is impaired as the disease progresses. Our studies demonstrated that NG2 cells were clustered around amyloid plaque. NG2 cells engulfed $A \beta_{42}$ through macropinocytosis. The internalized $A \beta_{42}$ was degraded by the autophagy. These findings identified a novel cell type that could participate in the clearance of $A \beta_{42}$ in the brain, which may provide a new insight into the mechanisms of $A \beta_{42}$ degradation. It also potentially offers new strategy for eliminating toxic senile plaques in AD.

\section{Materials and methods}

\section{Antibodies and reagents}

All culture dishes, plates and flasks were obtained from Corning. All chemicals, such as Thioflavine S (T1892), cytochalasin D (C2618), nocodazole (M1404), leupeptin (L9783), pepstatin A (P5318), wortmannin (W3144), bafilomycin A1 (B1793) and platelet-derived growth factor-AA (P3076) were obtained from Sigma-Aldrich unless otherwise mentioned. Fibroblast Growth Factor basic, human Animal-Free recombinant (bFGF, GF003AF) and Anti-NG2 (rabbit, AB5320) antibodies were obtained from Chemicon. Anti-beclin1 antibody (rabbit, 3495 s) was obtained from Cell Signaling Technology.
Anti-6E10 (mouse, sig-39320) antibody was obtained from Signet. Anti- LC3B (rabbit, L7543) was obtained from Sigma-Aldrich. Anti-GAPDH antibody (kc-5G5) was obtained from Kangcheng Bio-tech. HiLyte Fluor ${ }^{\mathrm{TM}}$ 555-labeled beta-amyloid (1-42) (60480-01) or HiLyte Fluor $^{\text {TM }}$ 488-labeled beta-amyloid (1-42) (60479-01) were obtained from Anaspec. Lysotracker(L7528), trizol (15596018) and anti-A $\beta(1-42)$ antibody(700254) were obtained from Invitrogen. Alex-labeled secondary antibodies were obtained from Molecular Probes. Colloidal gold-affinipure donkey anti-rabbit IgG (18 nm) was obtained from Jackson Laboratories. Agarose II (low gelling temperature biotechnology grade, 0815) was obtained from Amresco.

\section{Animal}

A rodent transgenic animal that expresses familial ADcausing mutated forms of human APP (APPswe, Swedish familial AD-causing mutation) and presenilin1 $(\mathrm{PS} 1 \triangle \mathrm{E} 9)$ (Jackson Laboratory) were used as an AD model. These animals develop amyloid deposits similar to those found in brains of humans diagnosed with AD [60,61]. Male SD rats at postnatal day 1-2 were obtained from Shanghai SLAC Laboratory Animal Co. Ltd. The procedure for animal surgery was performed in accordance with the Guidelines of Animal Care and Use Committee of the Institute for Nutritional Sciences, Shanghai Institutes for Biological Sciences (SIBS), Chinese Academy of Sciences. Every effort was made to minimize the number of animals used and their suffering.

\section{Sample collection}

For immunohistochemical analysis, animals were anesthetized by i.p. injection of chloral hydrate $(500 \mathrm{mg} / \mathrm{kg})$ and were perfused with $10 \mathrm{ml}$ of saline, followed by $100 \mathrm{ml}$ of $4 \%$ paraformaldehyde in $0.1 \mathrm{M}$ phosphate buffer $(\mathrm{PB}, \mathrm{pH}$ 7.2). The brains were removed and postfixed in the same fixative overnight, and then transferred to $30 \%$ sucrose for an additional $24 \mathrm{hrs}$ at $4^{\circ} \mathrm{C}$. The brain block was dissected on a Rodent Brain Matrix (ASI Instruments) and sectioned with a sliding microtome (Microm Laborgerate $\mathrm{GmbH}$ ) at the thickness of $40 \mu \mathrm{m}$. For immunoblotting analysis, cultured cells were collected and homogenized in an ice-cold lysis buffer containing $5 \mathrm{mM}$ EDTA, $0.5 \% \mathrm{NP}-40,0.1 \%$ Triton X100, 0.1\% SDS, $10 \mathrm{mg} / \mathrm{ml}$ PMSF, $10 \mu \mathrm{g} / \mathrm{ml}$ leupeptin and $100 \mathrm{mM}$ sodium orthovanadate in phosphate buffer saline (PBS). Homogenates were centrifuged at 14,000 revolutions per minute (rpm) for 30 minutes at $4^{\circ} \mathrm{C}$ and the supernatant fraction was collected. For real-time PCR analysis, animals were anesthetized by i.p. injection of chloral hydrate $(500 \mathrm{mg} / \mathrm{kg})$ and were perfused with $10 \mathrm{ml}$ of saline. The brains were removed and cerebral cortex were collected for total RNA extraction. 


\section{Immunohistochemical staining}

For immunofluorescence staining, sections were preincubated with $0.3 \%$ Triton X-100 in PBS for 10 minutes and blocked with $1 \%$ BSA, $0.1 \%$ Triton X-100 for 1 hour. Then the sections were incubated with anti-NG2 antibody (rabbit, 1:500) at $4^{\circ} \mathrm{C}$ overnight and the Alexa Fluor 555-conjugated goat anti- rabbit IgG (1:1000, Invitrogen, A-21428) at room temperature for 2 hours. After that, DAPI $(1 \mu \mathrm{g} / \mathrm{ml})$ was added in the washing buffer for 5 minutes. Brain sections were examined with an Olympus BX51 microscope (Olympus America Inc.) or Zeiss LSM 510 Meta confocal microscope (Carl Zeiss microImaging Inc.).

\section{Thioflavin-S staining}

The procedure for thioflavin-S staining has been previously described [62]. Briefly, sections were stained with $0.05 \%$ thioflavin-S in $50 \%$ ethanol in the dark for $8 \mathrm{mi}$ nutes, followed by two rinsing in $80 \%$ ethanol for $10 \mathrm{sec}-$ onds each and three washes in large volumes of distilled water. Slides were then incubated in a high concentration of phosphate buffer $(411 \mathrm{mM} \mathrm{NaCl}, 8.1 \mathrm{mM} \mathrm{KCl}$, $30 \mathrm{mM} \mathrm{Na}_{2} \mathrm{HPO}_{4}, 5.2 \mathrm{mM} \mathrm{KH_{2 }} \mathrm{PO}_{4}, \mathrm{pH} 7.2$ ) at $4^{\circ} \mathrm{C}$ for over 30 minutes. After that slides were briefly rinsed with distilled water, and then sealed with coverslips.

\section{Quantification of activated NG2 cells number}

NG2-positive cells with larger cell body, cell body stained more heavily with antibody against NG2, thicker and shorter processes were considered as activated NG2 cells $[19,20]$. Only NG2 cells with clearly visible nuclei were counted. The number of activated NG2 cells in the hippocampus was quantified by manually counting as previously described [23,63,64] with some modifications. Five animals of each group were used for the quantifications . For each mouse, the brain was sectioned at the thickness of $40 \mu \mathrm{m}$. Sections containing hippocampus were collected from the Bregma level $-1.22 \mathrm{~mm}$ to $-2.3 \mathrm{~mm}$. Every fifth section was collected and used for NG2 staining. Five sections per animal were used for quantifications. Digital images are acquired by a Olympus BX51 microscope system equipped with a DP72 digital camera (Olympus America Inc.) using a $10 \times$ objective lens. All parameters were held constant for all sections. The area of hippocampus was measured by ImageJ $(1.44 \mathrm{p})$. The result was presented as number of activated NG2 cells per unit area (number of activated NG2 cells $/ \mathrm{mm}^{2}$ ).

\section{Cell cultures}

Primary rat oligodendrocyte precursor cells were derived from the brains of SD rat at postnatal day 1-2 as previously described [65] with some modifications. Briefly, cerebral cortices from postnatal day 1-2 SD rats were dissected, minced and digested. Dissociated cells from one rat were plated in two $75 \mathrm{~cm}^{2}$ tissue culture flasks coated by $100 \mu \mathrm{g} / \mathrm{ml}$ Poly-D-Lysine(Sigma-Aldrich, p7886). Cell cultures were maintained in Dulbecco's modified Eagle's medium (DMEM, Invitrogen, 12100046) supplemented with $10 \%$ fetal bovine serum (Hyclone, SV30087.02), 10\% of horse serum (Invitrogen, 26050-088), $100 \mathrm{U} / \mathrm{ml}$ streptomycin and $100 \mathrm{U} / \mathrm{ml}$ penicillin G (Invitrogen, GB15140-122) at $37^{\circ} \mathrm{C}$ in humidified air with $5 \% \mathrm{CO}_{2}$ for 7 to 10 days without changing the culture medium. After that, the flasks were sealed and shaken at $230 \mathrm{rpm}$ at $37^{\circ} \mathrm{C}$ for 3 hours to remove microglial cells. The medium was removed and replaced with $10 \mathrm{ml}$ DMEM containing 10\% fetal bovine serum, $10 \%$ of horse serum, $100 \mathrm{U} / \mathrm{ml}$ streptomycin and $100 \mathrm{U} / \mathrm{ml}$ penicillin $\mathrm{G}$. The flasks were shaken again for 20 hours at $260 \mathrm{rpm}$ at $37^{\circ} \mathrm{C}$. The medium containing floating cells was collected and placed in Petri dishes for 30 minutes at $37^{\circ} \mathrm{C}$. The non-adherent cells (oligodendrocyte precursor cells) were collected and replated on a Poly-D-Lysine-coated 24-well plate at a density of $5 \times 10^{4}$ cells/well. Cells were maintained in SATO medium containing $1 \%$ horse serum, $10 \mathrm{ng} / \mathrm{ml}$ plateletderived growth factor, and $5 \mathrm{ng} / \mathrm{ml}$ bFGF. The NG2 cell line was kindly provided by Dr. Jacqueline Trotter (Johannes Gutenberg University of Mainz, Mainz, Germany) and cultured on Poly-D-Lysine coated coverslips in SATO medium containing 1\% horse serum [66]. The NG2 cell line was a murine oligodendroglial precursor cell line and generated by immortalization of mitotic oligodendrocyte precursor cells with retroviral vectors containing the $t$-neu oncogene. The cell line has the properties of oligodendrocyte precursor and can differentiate into myelin-associated glycoprotein (MAG)-positive oligodendrocytes. It is a widely used as oligodendrocyte precursor cells in many in vitro studies [67-69].

\section{$A \beta_{42}$ preparation}

Soluble species of $A \beta_{42}$ was prepared according to the instruction of the manufacturer (Anaspec). Briefly, the lyophilized $\mathrm{A} \beta_{42}$ peptide powder was dissolved in $1.0 \%$ $\mathrm{NH}_{4} \mathrm{OH}$ (provided by the manufacturer) to get a stock solution. Immediately dilute this stock solution with $1 \times$ PBS to a concentration of approximately $1 \mathrm{mg} / \mathrm{mL}$. Gently vortex to mix. Reconstituted peptide was aliquoted into several freezer vials and stored at $-80^{\circ} \mathrm{C}$.

\section{Immunocytochemistry}

Primary oligodendrocyte precursor cells and NG2 cell line were plated on coverslips in a 24-well plate at a density of $5 \times 10^{4}$ and $3 \times 10^{4}$ cells/well, respectively for 18 hours. Cells were incubated with HiLyte Fluor ${ }^{\mathrm{TM}} 555$ or 488-labeled $\mathrm{A} \beta_{42}(2 \mu \mathrm{M})$ for 24 hours, and then fixed in $4 \%$ paraformaldehyde. After permeabilization with $0.1 \%$ Triton X-100, cells were washed with PBS three 
times and blocked in a solution containing 3\% BSA and $0.1 \%$ Triton X-100 in PBS for 1 hour. Cells were incubated with primary anti-NG2 antibody (1:500) at $4^{\circ} \mathrm{C}$ overnight and then washed three times with PBS, incubated with Alexa488- or 555-conjugated goat anti-rabbit secondary antibodies at a 1:1000 dilution for 1 hour, and then $1 \mu \mathrm{g} / \mathrm{ml}$ DAPI for 5 minutes. Coverslips were mounted on slides and observed using a Zeiss LSM 510 Meta confocal microscope (Carl Zeiss microImaging Inc.). For $A \beta_{42}$ 's uptake study, the NG2 cell line were incubated with HiLyte Fluor $^{\text {rn }} 488$-labeled $\mathrm{A} \beta_{42}(400 \mathrm{nM})$ for the indicated times. Cells were fixed in $4 \%$ paraformaldehyde. After permeabilization with $0.1 \%$ Triton X-100, cells were blocked in a solution containing 3\% BSA and $0.1 \%$ Triton X-100 in PBS for 1 hour. Cells were then processed for NG2 immunocytochemistry as described above. For visualizing lysosomes, the cells were labeled with lysotracker (40 nM, 30 minutes) and then fixed, permeabilized and stained with DAPI.

\section{Transmission electron microscopy}

Immunoelectron microscopy was performed as described previously [70,71]. NG2 cell line treated with $\mathrm{A} \beta_{42}$ for 6 hours was collected and fixed with $2.5 \%$ glutaraldehyde in $0.1 \mathrm{M}$ phosphate buffered saline (PBS; $\mathrm{pH}$ 7.4) at room temperature for 1 hour and washed 3 times with PBS. The cell pellets were then embedded in $2 \%$ agarose II and postfixed with $1 \%$ Osmium tetroxide at room temperature for 1 hour. The fixed cell pellets were rinsed three times with distilled water and three times with PBS. The pellets were dehydrated through an ethanol $(\mathrm{EtOH})$ dilution series up to $100 \% \mathrm{EtOH}$ and then infiltrated in propylene oxide/ Epon812 resin mixture. Then the pellets were infiltrated in 100\% Epon 812 for 1 hour. Subsequently, the pellets were embedded in 100\% Eponate resin and sectioned. Ultrathin sections were treated with $1 \%$ sodium periodate for 10 minutes. After washed with $d_{d d H_{2}} \mathrm{O}$, sections were blocked in $2 \%$ FBS in PBS without $\mathrm{Ca}^{2+} / \mathrm{Mg}^{2+}$ for 30 minutes and incubated with rabbit anti-A $\beta_{42}$ IgG antibody (1:250) overnight at $4^{\circ} \mathrm{C}$ followed by donkey anti-rabbit antibody conjugated to colloidal gold (18 $\mathrm{nm}$ particle for $\mathrm{A} \beta_{42}$ (1:20), Jackson Laboratories) for 2 hours at room temperature. Sections were double-stained with uranyl acetate and lead citrate, and examined under a JEOL JEM1230 electron microscope (JEOL).

\section{Quantification of $A \beta_{42}$ by flow cytometry}

Quantification of $A \beta_{42}$ by flow cytometry was performed as previously described with some modifications [27]. Briefly, primary oligodendrocyte precursor cells and NG2 cell line were plated at a density of $2 \times 10^{5}$ cells/well in a 6-well plate overnight. The cells were incubated with HiLyte Fluor ${ }^{\text {rit }} 488-\mathrm{A} \beta_{42}(400 \mathrm{nM})$ for the indicated times.
For nocodazole and cytochalasin D treatment, NG2 cells were preincubated with $150 \mathrm{nM}$ nocodazole and $5 \mu \mathrm{g} / \mathrm{ml}$ cytochalasin $\mathrm{D}$ for 30 minutes and then incubated with HiLyte Fluor ${ }^{\text {Tn }} 488-\mathrm{A} \beta_{42}(400 \mathrm{nM})$ for the indicated times. Cells were removed by the treatment of $0.01 \%$ trypsin (Invitrogen, 25200-072), centrifuged at 1,000 g for 5 minutes, and washed with PBS twice. After that, cells were resuspended in PBS for the analysis using a FACScan cytometer (BD Biosciences) equipped with a FITC signal detector FL1 (excitation $488 \mathrm{~nm}$, green).

\section{Immunoblotting}

The procedure for immunoblotting was previously described [72]. Briefly, proteins were loaded into the lanes of a sodium dodecyl sulfate polyacrylamide gel (SDSPAGE) or tricine sodium dodecyl sulfate polyacrylamide gel (Tricine-SDS-PAGE). The proteins were separated by electrophoresis and transferred to nitrocellulose membranes $(0.45$ or $0.22 \mu \mathrm{m}$, Schleicher \& Schuell). The membranes were blocked with $5 \%$ nonfat dry milk in $0.01 \mathrm{M} \mathrm{PBS}$ (pH 7.4) and 0.05\% Tween-20 (TPBS) at room temperature for 1 hour. Subsequently, the membrane was incubated with primary antibodies directed against target proteins overnight at $4^{\circ} \mathrm{C}$. The final dilutions for primary antibodies were: $6 \mathrm{E} 10(1: 1,000)$, LC3 $(1: 2,000)$, and Beclin1 (1:2,000). After three quick washes in TPBS, the membranes were incubated with secondary antibodies conjugated to horseradish peroxidase (Amersham) diluted at 1:5,000 in TPBS for 1 hour. The immunocomplexes were detected by the enhanced chemiluminescence method (Amersham, RPN2106). The density of immunoblotting was quantified with the software of Quantity One (Bio-Rad Laboratories).

\section{Assaying $A \beta_{42}$ degradation}

The analysis for $A \beta_{42}$ degradation in the NG2 cell line was performed as previously described [24]. NG2 cell line $\left(5 \times 10^{5}\right.$ cells/well $)$ cultured in Sato medium containing $1 \%$ horse serum was exposed to human $A \beta_{42}$ $(400 \mathrm{nM}) . A \beta_{42}$ levels in cell-culture supernatants and adherent cells were determined by immunoblotting. For some experiments, NG2 cell line was incubated with HiLyte Fluor $^{\mathrm{rm}} 488-\mathrm{A} \beta_{42}(400 \mathrm{nM})$ for 6 hours, followed by the treatment of leupeptin $(20 \mu \mathrm{M})$, pepstatin A $(20 \mu \mathrm{M})$, wortmannin, and bafilomycin $\mathrm{A} 1(0.2 \mathrm{nM})$ for 18 hours. The protein levels of $A \beta_{42}$, LC3, and beclin1 were determined by immunoblotting.

\section{Real-time PCR}

NG2 cell line was incubated with HiLyte Fluor $^{\text {Ti }}$ 488labeled $A \beta_{42}(400 \mathrm{nM})$ for the indicated times. Total RNA extraction and reverse transcription for NG2 cell line and cerebral cortex were performed as previously reported [72] with some modifications. Briefly, total 
RNA was extracted using Trizol reagent (Invitrogen, 15596018). After treated with RNase-free DNase I (Roche Applied Science, 10104159001), first strand cDNA was synthesized with M-MLV reverse transcriptase (Promega, M1701) and Oligo-dTs (Promega, C1101). Real-time quantitative PCR was conducted with ABI Prism 7500 Sequence Detection System according to the instruction of the manufacturer (Applied Biosystems). Dissociation curve analyses were performed using the instrument's default setting immediately after each PCR run to ensure specificity. The expression level of target genes was normalized to the actin gene. The primers which were used for real time PCR are provided in the following Table 1.

\section{Small RNA interference}

Small interfering RNAs were synthesized by Shanghai GenePharma Co., Ltd. The siRNA sequences for mouse beclin1, siRNA-1: sense 5'-GAGGAGCCAUUUAUUG AAACUCG-3' and antisense 5' -CGAGUUUCAAUAAA UGGCUCCUC-3'; siRNA-2: sense 5'-GGACAACAAG UUUGACCAUGC-3' and antisense 5'-GCAUGGUCAA ACUUGUUGUCC-3'; for siRNA control, oligos with no matching GeneBank sequence were used: sense $5^{\prime}$-GC GACGAUCUGCCUAAGAU-3' and antisense $5^{\prime}$-AUC UUAGGCAGAUCGUCGC-3'. The pairs of siRNA oligonucleotides were prepared as a $20 \mu \mathrm{M}$ stock. For transient transfection, NG2 cell line was cultured in six-well plates to $80 \%$ confluence and transfected with Lipofectamine ${ }^{\text {TM }}$ RNAiMAX (Invitrogen, 13778-150) according to the manufacturer's instructions. After transfection, the cells were left for another 24 hours before they were used for experiments.

\section{Quantification of the mCherry-LC3 puncta}

Human microtubule-associated protein 1 light chain 3 beta (MAP1LC3B, Gene ID: 81631) was cloned from a cDNA of HEK-293 (ATCC, CRL-1573) with forward primer (5' - CAA CAA GCT TCC ATG CCG TCG GAG AAG ACC $-3^{\prime}$ ) and reverse primer (5' - CGC GGA TCC

\section{Table 1 Primers for real time PCR}

\begin{tabular}{ll}
\hline Gene & Primer \\
\hline Mouse-LAMP1-sense & CAGCACTCTTTGAGGTGAAAAAC \\
Mouse-LAMP1-antisense & ACGATCTGAGAACCATTCGCA \\
Mouse-LAMP2-sense & ATATGTGCAACAAAGAGCAGGT \\
Mouse-LAMP2-antisense & TGCCAATTAGGTAAGCAATCACT \\
Mouse-NG2-sense & CCCCCCCATACCCATGTC \\
Mouse-NG2-antisense & CGATCGGAAATAACCTGAAGCT \\
Mouse-ACtin-sense & CAACGAGCGGTTCCGAT \\
Mouse-ACtin-antisense & GCCACAGGATTCCATACCCA \\
\hline
\end{tabular}

TTA CAC TGA CAA TTT CAT CCC G $\left.-3^{\prime}\right)$. The nucleotide sequence was inserted into mCherry-C1 vector (a gift from Dr. Kang, JS, INS, SIBS, CAS) at the Hind III and BamH I restriction sites. The plasmid was verified by sequencing (Invitrogen). The mCherry-LC3 was transiently transfected NG2 cell line using Lipofectamine ${ }^{\mathrm{TM}} 2000$ (Invitrogen, 11668019) following the manufacturer's instructions. After transfection, the cells were treated with HiLyte Fluor $^{\mathrm{TM}}$ 488-labeled $\mathrm{A} \beta_{42}(400 \mathrm{nM})$ for 18 hours. After that, cells were fixed in $4 \%$ paraformaldehyde, permeabilized with $0.1 \%$ Triton $\mathrm{X}-100$, and incubated with DAPI $(1 \mu \mathrm{g} / \mathrm{ml})$ for 5 minutes. Cells were examined using the Olympus BX51 microscope system equipped with a DP72 digital camera (Olympus America Inc.).

To analyze the formation number of autophagosomes, we determined mCherry-LC3 (the plasmid was kindly provided by Dr. Jiansheng Kang) puncta in cells. The cells were classified as (a) cells with diffuse mCherry-LC3 fluorescence or with few mCherry-LC3 puncta ( $<20$ dots/cell) and (b) cells with numerous mCherry-LC3 puncta $(>20$ dots/cell), representing autophagosomes [73]. At least 200 cells per sample were scored for each condition in three independent experiments. The percentage of mCherryLC3-positive cells with mCherry-LC3 punctate dots were calculated [74].

\section{Statistical analysis}

Statistical analysis was assessed by ANOVA followed by Student-Newman-Keuls analyses. An unpaired $t$ test was used for the analysis of quantitative data of bafilomycin A1. Two-way ANOVA was used for the analysis of quantitative data of activated NG2 cells number. Data were presented as means \pm SD. Difference in which $\mathrm{p}<0.05$ was considered statistically significant.

\section{Abbreviations}

AD: Alzheimer's disease; ALP: Autophagy/lysosome pathway; ApoE: Apolipoprotein E; APP: Amyloid $\beta$ precursor protein; APPsw: Swedish mutant APP; ATPase: Adenosine triphosphatase; A $\beta$ : Amyloid $\beta$ peptide; Baf: Bafilomycin A1; bFGF: Fibroblast growth factor basic; BSA: Bovine serum albumin; CNS: Central nervous system; CytoD: Cytochalasin D; DAPI: 4,6-diamidino2-phenylindole; DMEM: Dulbecco's modified eagle medium; FPRL1: Formyl peptide receptor-like 1; GAPDH: Glyceraldehyde-3-phosphate dehydrogenase; GTPase: Guanosine triphosphatase; LAMP1: Lysosome-associated membrane glycoprotein 1; LAMP2: Lysosome-associated membrane glycoprotein 2; LC3B: Microtubule-associated protein 1 light chain 3 beta; LDLR: Low-density lipoprotein receptor; Leu: Leupeptin; LIR: LC3-interacting region; MAG: Myelinassociated glycoprotein; mRNA: Messenger RNA; NCDZ: Nocodazole; NFTs: Neurofibrillary tangles; OPC: Oligodendroglial precursor cells; PAS: Pre-autophagosomal structure; PBS: Phosphate buffer saline; PDGF AA: Platelet-derived growth factor-AA; PE: Phophatidylethanolamine; Pep: Pepstatin A; PI3K: Phosphatidylinositol 3-kinases; RAGE: Scavenger receptor for advanced glycation end products; Rpm: Revolutions per minute; RT-PCR: Real time-polymerase chain reaction; siRNA: Small interfering RNAs; Thio-s: Thioflavine S; TLRs: Toll-like receptors; UPP: Ubiquitin/proteasome pathway. 


\section{Competing interests}

The authors declare that they have no competing interests.

\section{Authors' contributions}

WL, YT, ZF, YM and GY carried out all of the experiments. ZK and $J$ participated in the design of the study and the writing of the manuscript. All authors read and approved the final manuscript.

\section{Acknowledgements}

We would like to thank Jacqueline A. Frank for reading this manuscript. This research was supported by grants from the Ministry of Science and Technology of China (2010CB912000; 2007CB947100), the National Natural Science Foundation of China $(31271142,30870812)$, the Chief Scientist Program of Shanghai Institutes for Biological Sciences, Chinese Academy of Sciences (SIBS2008006), the Program of Clinical Research Center, Institute for Nutritional Sciences and Xuhui Central Hospital (CRC20100010), the Knowledge Innovation Program of the Chinese Academy of Sciences (KSCX2-EW-R-08). Dr J. Luo was supported by a grant from NIH/NIAAA (AA015407).

\section{Author details}

${ }^{1}$ Key Laboratory of Nutrition and Metabolism, Institute for Nutritional Sciences, Shanghai Institutes for Biological Sciences, Chinese Academy of Sciences, Graduate School of the Chinese Academy of Sciences, Shanghai 200031, China. ${ }^{2}$ Department of Internal Medicine, University of Kentucky College of Medicine, Lexington, KY 40536, USA. ${ }^{3}$ Shanghai Clinical Center, CAS / Shanghai Xuhui Central Hospital, Shanghai, China.

Received: 21 February 2013 Accepted: 6 August 2013 Published: 10 August 2013

\section{References}

1. Selkoe DJ: Alzheimer's disease: genes, proteins, and therapy. Physio/ Rev 2001, 81:741-766.

2. Querfurth HW, LaFerla FM: Alzheimer's disease. N Engl J Med 2010, 362:329-344.

3. Tanzi RE, Bertram L: Twenty years of the Alzheimer's disease amyloid hypothesis: a genetic perspective. Cell 2005, 120:545-555.

4. LaFerla FM, Green KN, Oddo S: Intracellular amyloid-beta in Alzheimer's disease. Nat Rev Neurosci 2007, 8:499-509.

5. Wong E, Cuervo AM: Autophagy gone awry in neurodegenerative diseases. Nat Neurosci 2010, 13:805-811.

6. Hara T, Nakamura K, Matsui M, Yamamoto A, Nakahara Y, Suzuki-Migishima R, Yokoyama M, Mishima K, Saito I, Okano H, Mizushima N: Suppression of basal autophagy in neural cells causes neurodegenerative disease in mice. Nature 2006, 441:885-889.

7. Pickford F, Masliah E, Britschgi M, Lucin K, Narasimhan R, Jaeger PA, Small S, Spencer B, Rockenstein E, Levine B, Wyss-Coray T: The autophagy-related protein beclin 1 shows reduced expression in early Alzheimer disease and regulates amyloid beta accumulation in mice. J Clin Invest 2008, 118:2190-2199.

8. Levine JM, Card JP: Light and electron microscopic localization of a cell surface antigen (NG2) in the rat cerebellum: association with smooth protoplasmic astrocytes. J Neurosci 1987, 7:2711-2720.

9. Levine JM, Reynolds R, Fawcett JW: The oligodendrocyte precursor cell in health and disease. Trends Neurosci 2001, 24:39-47.

10. Nishiyama A: Polydendrocytes: NG2 cells with many roles in development and repair of the CNS. Neuroscientist 2007, 13:62-76.

11. Dawson MR, Levine JM, Reynolds R: NG2-expressing cells in the central nervous system: are they oligodendroglial progenitors? J Neurosci Res 2000, 61:471-479.

12. Butt AM, Duncan A, Hornby MF, Kirvell SL, Hunter A, Levine JM, Berry M: Cells expressing the NG2 antigen contact nodes of Ranvier in adult CNS white matter. Glia 1999, 26:84-91.

13. Bergles DE, Roberts JD, Somogyi P, Jahr CE: Glutamatergic synapses on oligodendrocyte precursor cells in the hippocampus. Nature 2000, 405:187-191.

14. Ge WP, Yang XJ, Zhang Z, Wang HK, Shen W, Deng QD, Duan S: Long-term potentiation of neuron-glia synapses mediated by Ca2 + -permeable AMPA receptors. Science 2006, 312:1533-1537.
15. Belachew S, Chittajallu R, Aguirre AA, Yuan X, Kirby M, Anderson S, Gallo V: Postnatal NG2 proteoglycan-expressing progenitor cells are intrinsically multipotent and generate functional neurons. J Cell Biol 2003, 161:169-186.

16. Rivers LE, Young KM, Rizzi M, Jamen F, Psachoulia K, Wade A, Kessaris N, Richardson WD: PDGFRA/NG2 glia generate myelinating oligodendrocytes and piriform projection neurons in adult mice. Nat Neurosci 2008, 11:1392-1401.

17. Jones LL, Yamaguchi Y, Stallcup WB, Tuszynski MH: NG2 is a major chondroitin sulfate proteoglycan produced after spinal cord injury and is expressed by macrophages and oligodendrocyte progenitors. J Neurosci 2002, 22:2792-2803.

18. Ong WY, Levine JM: A light and electron microscopic study of NG2 chondroitin sulfate proteoglycan-positive oligodendrocyte precursor cells in the normal and kainate-lesioned rat hippocampus. Neuroscience 1999, 92:83-95.

19. Levine JM, Enquist LW, Card JP: Reactions of oligodendrocyte precursor cells to alpha herpesvirus infection of the central nervous system. Glia 1998, 23:316-328.

20. Fiedorowicz A, Figiel I, Zaremba M, Dzwonek K, Oderfeld-Nowak B: The ameboid phenotype of NG2 (+) cells in the region of apoptotic dentate granule neurons in trimethyltin intoxicated mice shares antigen properties with microglia/macrophages. Glia 2008, 56:209-222.

21. Levine JM: Increased expression of the NG2 chondroitin-sulfate proteoglycan after brain injury. J Neurosci 1994, 14:4716-4730.

22. Bu J, Akhtar N, Nishiyama A: Transient expression of the NG2 proteoglycan by a subpopulation of activated macrophages in an excitotoxic hippocampal lesion. Glia 2001, 34:296-310.

23. McTigue DM, Wei P, Stokes BT: Proliferation of NG2-positive cells and altered oligodendrocyte numbers in the contused rat spinal cord. J Neurosci 2001 21:3392-3400.

24. Wyss-Coray T, Loike JD, Brionne TC, Lu E, Anankov R, Yan F, Silverstein SC, Husemann J: Adult mouse astrocytes degrade amyloid-beta in vitro and in situ. Nat Med 2003, 9:453-457.

25. Koistinaho M, Lin S, Wu X, Esterman M, Koger D, Hanson J, Higgs R, Liu F, Malkani S, Bales KR, Paul SM: Apolipoprotein E promotes astrocyte colocalization and degradation of deposited amyloid-beta peptides. Nat Med 2004, 10:719-726.

26. Simard AR, Soulet D, Gowing G, Julien JP, Rivest S: Bone marrow-derived microglia play a critical role in restricting senile plaque formation in Alzheimer's disease. Neuron 2006, 49:489-502.

27. Mandrekar S, Jiang Q, Lee CY, Koenigsknecht-Talboo J, Holtzman DM, Landreth GE: Microglia mediate the clearance of soluble Abeta through fluid phase macropinocytosis. J Neurosci 2009, 29:4252-4262.

28. Vingtdeux V, Giliberto L, Zhao H, Chandakkar P, Wu Q, Simon JE, Janle EM, Lobo J, Ferruzzi MG, Davies P, Marambaud P: AMP-activated protein kinase signaling activation by resveratrol modulates amyloid-beta peptide metabolism. J Biol Chem 2010, 285:9100-9113.

29. Lunemann JD, Schmidt J, Schmid D, Barthel K, Wrede A, Dalakas MC, Munz $\mathrm{C}$ : Beta-amyloid is a substrate of autophagy in sporadic inclusion body myositis. Ann Neurol 2007, 61:476-483.

30. Nixon RA: Autophagy, amyloidogenesis and Alzheimer disease. J Cell Sci 2007, 120:4081-4091.

31. Markesbery WR: Oxidative stress hypothesis in Alzheimer's disease. Free Radic Biol Med 1997, 23:134-147.

32. Wyss-Coray T: Inflammation in Alzheimer disease: driving force, bystander or beneficial response? Nat Med 2006, 12:1005-1015.

33. Bateman RJ, Munsell LY, Morris JC, Swarm R, Yarasheski KE, Holtzman DM: Human amyloid-beta synthesis and clearance rates as measured in cerebrospinal fluid in vivo. Nat Med 2006, 12:856-861.

34. Chung $H$, Brazil Ml, Soe $\Pi$, Maxfield FR: Uptake, degradation, and release of fibrillar and soluble forms of Alzheimer's amyloid beta-peptide by microglial cells. J Biol Chem 1999, 274:32301-32308.

35. El Khoury J, Luster AD: Mechanisms of microglia accumulation in Alzheimer's disease: therapeutic implications. Trends Pharmacol Sci 2008, 29:626-632.

36. Kerr MC, Lindsay MR, Luetterforst R, Hamilton N, Simpson F, Parton RG, Gleeson PA, Teasdale RD: Visualisation of macropinosome maturation by the recruitment of sorting nexins. J Cell Sci 2006, 119:3967-3980.

37. Mercer J, Helenius A: Virus entry by macropinocytosis. Nat Cell Biol 2009, 11:510-520 
38. Kerr MC, Teasdale RD: Defining macropinocytosis. Traffic 2009, 10:364-371.

39. Gruenberg J, Griffiths G, Howell KE: Characterization of the early endosome and putative endocytic carrier vesicles in vivo and with an assay of vesicle fusion in vitro. J Cell Biol 1989, 108:1301-1316.

40. Gruenberg J, Maxfield FR: Membrane transport in the endocytic pathway. Curr Opin Cell Biol 1995, 7:552-563.

41. Matteoni R, Kreis TE: Translocation and clustering of endosomes and lysosomes depends on microtubules. J Cell Biol 1987, 105:1253-1265.

42. Yan SD, Chen X, Fu J, Chen M, Zhu H, Roher A, Slattery T, Zhao L, Nagashima M, Morser J, et al: RAGE and amyloid-beta peptide neurotoxicity in Alzheimer's disease. Nature 1996, 382:685-691.

43. Yazawa H, Yu ZX, Takeda Le Y, Gong W, Ferrans VJ, Oppenheim JJ, Li CC, Wang JM: Beta amyloid peptide (Abeta42) is internalized via the Gprotein-coupled receptor FPRL1 and forms fibrillar aggregates in macrophages. FASEB J 2001, 15:2454-2462.

44. Le Y, Gong W, Tiffany HL, Tumanov A, Nedospasov S, Shen W, Dunlop NM, Gao JL, Murphy PM, Oppenheim JJ, Wang JM: Amyloid (beta)42 activates a G-protein-coupled chemoattractant receptor, FPR-like-1. J Neurosci 2001, 21:RC123.

45. Tahara K, Kim HD, Jin JJ, Maxwell JA, Li L, Fukuchi K: Role of toll-like receptor signalling in Abeta uptake and clearance. Brain 2006, 129:3006-3019.

46. Buckingham SD, Jones AK, Brown LA, Sattelle DB: Nicotinic acetylcholine receptor signalling: roles in Alzheimer's disease and amyloid neuroprotection. Pharmacol Rev 2009, 61:39-61.

47. Bu G: Apolipoprotein E and its receptors in Alzheimer's disease: pathways, pathogenesis and therapy. Nat Rev Neurosci 2009, 10:333-344.

48. Bu G, Cam J, Zerbinatti C: LRP in amyloid-beta production and metabolism. Ann N Y Acad Sci 2006, 1086:35-53.

49. Deane R, Du Yan S, Submamaryan RK, LaRue B, Jovanovic S, Hogg E, Welch D, Manness L, Lin C, Yu J, et al: RAGE mediates amyloid-beta peptide transport across the blood-brain barrier and accumulation in brain. Nat Med 2003, 9:907-913.

50. Pandey UB, Batlevi Y, Baehrecke EH, Taylor JP: HDAC6 at the intersection of autophagy, the ubiquitin-proteasome system and neurodegeneration. Autophagy 2007, 3:643-645.

51. Pandey UB, Nie Z, Batlevi Y, McCray BA, Ritson GP, Nedelsky NB, Schwartz SL, DiProspero NA, Knight MA, Schuldiner O, et al: HDAC6 rescues neurodegeneration and provides an essential link between autophagy and the UPS. Nature 2007, 447:859-863.

52. Cataldo AM, Barnett JL, Berman SA, Li J, Quarless S, Bursztajn S, Lippa C, Nixon RA: Gene expression and cellular content of cathepsin $D$ in Alzheimer's disease brain: evidence for early up-regulation of the endosomal-Iysosomal system. Neuron 1995, 14:671-680.

53. Cataldo AM, Barnett JL, Pieroni C, Nixon RA: Increased neuronal endocytosis and protease delivery to early endosomes in sporadic Alzheimer's disease: neuropathologic evidence for a mechanism of increased beta-amyloidogenesis. J Neurosci 1997, 17:6142-6151.

54. Nixon RA, Wegiel J, Kumar A, Yu WH, Peterhoff C, Cataldo A, Cuervo AM: Extensive involvement of autophagy in Alzheimer disease: an immunoelectron microscopy study. J Neuropathol Exp Neurol 2005, 64:113-122.

55. Mueller-Steiner S, Zhou Y, Arai H, Roberson ED, Sun B, Chen J, Wang X, Yu G, Esposito L, Mucke L, Gan L: Antiamyloidogenic and neuroprotective functions of cathepsin B: implications for Alzheimer's disease. Neuron 2006, 51:703-714.

56. Yang CN, Shiao YJ, Shie FS, Guo BS, Chen PH, Cho CY, Chen YJ, Huang FL, Tsay HJ: Mechanism mediating oligomeric Abeta clearance by naive primary microglia. Neurobiol Dis 2011, 42:221-230.

57. Liang XH, Jackson S, Seaman M, Brown K, Kempkes B, Hibshoosh H, Levine $B$ : Induction of autophagy and inhibition of tumorigenesis by beclin 1 . Nature 1999, 402:672-676.

58. Yue Z, Jin S, Yang C, Levine AJ, Heintz N: Beclin 1, an autophagy gene essential for early embryonic development, is a haploinsufficient tumor suppressor. Proc Natl Acad Sci USA 2003, 100:15077-15082.

59. Zeng $\mathrm{X}$, Overmeyer $\mathrm{JH}$, Maltese WA: Functional specificity of the mammalian Beclin-Vps34 PI 3-kinase complex in macroautophagy versus endocytosis and lysosomal enzyme trafficking. J Cell Sci 2006, 119:259-270.

60. Jankowsky JL, Slunt HH, Ratovitski T, Jenkins NA, Copeland NG, Borchelt DR: Co-expression of multiple transgenes in mouse CNS: a comparison of strategies. Biomol Eng 2001, 17:157-165.

61. Jankowsky JL, Slunt HH, Gonzales V, Jenkins NA, Copeland NG, Borchelt DR: APP processing and amyloid deposition in mice haplo-insufficient for presenilin 1. Neurobiol Aging 2004, 25:885-892.
62. Sun A, Liu M, Nguyen XV, Bing G: P38 MAP kinase is activated at early stages in Alzheimer's disease brain. Exp Neurol 2003, 183:394-405.

63. Stephenson DT, O'Neill SM, Narayan S, Tiwari A, Arnold E, Samaroo HD, Du F, Ring RH, Campbell B, Pletcher M, et al: Histopathologic characterization of the BTBR mouse model of autistic-like behavior reveals selective changes in neurodevelopmental proteins and adult hippocampal neurogenesis. Mol Autism 2011, 2:7.

64. Komitova M, Zhu X, Serwanski DR, Nishiyama A: NG2 cells are distinct from neurogenic cells in the postnatal mouse subventricular zone. J Comp Neurol 2009, 512:702-716.

65. Chen Y, Balasubramaniyan V, Peng J, Hurlock EC, Tallquist M, Li J, Lu QR: Isolation and culture of rat and mouse oligodendrocyte precursor cells. Nat Protoc 2007, 2:1044-1051.

66. Jung M, Kramer E, Grzenkowski M, Tang K, Blakemore W, Aguzzi A, Khazaie K, Chlichlia K, Von Blankenfeld G, Kettenmann H, et al: Lines of murine oligodendroglial precursor cells immortalized by an activated neu tyrosine kinase show distinct degrees of interaction with axons in vitro and in vivo. Eur J Neurosci 1995, 7:1245-1265.

67. Gobert RP, Joubert L, Curchod ML, Salvat C, Foucault I, Jorand-Lebrun C, Lamarine M, Peixoto H, Vignaud C, Fremaux C, et al: Convergent functional genomics of oligodendrocyte differentiation identifies multiple autoinhibitory signaling circuits. Mol Cell Biol 2009, 29:1538-1553.

68. He Y, Dupree J, Wang J, Sandoval J, Li J, Liu H, Shi Y, Nave KA, CasacciaBonnefil P: The transcription factor Yin Yang 1 is essential for oligodendrocyte progenitor differentiation. Neuron 2007, 55:217-230.

69. Raju CS, Goritz C, Nord Y, Hermanson O, Lopez-Iglesias C, Visa N, CasteloBranco G, Percipalle P: In cultured oligodendrocytes the A/B-type hnRNP CBF-A accompanies MBP mRNA bound to mRNA trafficking sequences. Mol Biol Cell 2008, 19:3008-3019.

70. Li J, Ni M, Lee B, Barron E, Hinton DR, Lee AS: The unfolded protein response regulator GRP78/BiP is required for endoplasmic reticulum integrity and stress-induced autophagy in mammalian cells. Cell Death Differ 2008, 15:1460-1471.

71. Wang X, Wang B, Fan Z, Shi X, Ke Z, Luo J: Thiamine deficiency induces endoplasmic reticulum stress in neurons. Neuroscience 2007, 144:1045-1056.

72. Yang G, Meng Y, Li W, Yong Y, Fan Z, Ding H, Wei Y, Luo J, Ke ZJ: Neuronal MCP-1 mediates microglia recruitment and neurodegeneration induced by the mild impairment of oxidative metabolism. Brain Pathol 2011, 21:279-297.

73. Yitzhaki S, Huang C, Liu W, Lee Y, Gustafsson AB, Mentzer RM Jr, Gottlieb RA: Autophagy is required for preconditioning by the adenosine $\mathrm{A} 1$ receptor-selective agonist CCPA. Basic Res Cardiol 2009, 104:157-167.

74. Di Bartolomeo S, Corazzari M, Nazio F, Oliverio S, Lisi G, Antonioli M, Pagliarini V, Matteoni S, Fuoco C, Giunta L, et al: The dynamic interaction of AMBRA1 with the dynein motor complex regulates mammalian autophagy. J Cell Biol 2010, 191:155-168.

doi:10.1186/1750-1326-8-27

Cite this article as: Li et al.: Autophagy is involved in oligodendroglial precursor-mediated clearance of amyloid peptide. Molecular Neurodegeneration 2013 8:27.

\section{Submit your next manuscript to BioMed Central and take full advantage of:}

- Convenient online submission

- Thorough peer review

- No space constraints or color figure charges

- Immediate publication on acceptance

- Inclusion in PubMed, CAS, Scopus and Google Scholar

- Research which is freely available for redistribution 